\title{
CUSTOMER RELATIONSHIP MANAGEMENT INFLUENCE ON SALES OF SELECTED COMPANIES
}

\author{
J. Němeček \\ Received: November 30, 2011
}

\begin{abstract}
NĚMEČEK, J.: Customer relationship management influence on sales of selected companies. Acta univ. agric. et silvic. Mendel. Brun., 2012, LX, No. 2, pp. 231-236

General awareness of information technology and business strategy Customer Relationship Management (CRM) among managers in the Czech Republic is for several years, but in comparison with Western states of the European Union the Czech companies are underdeveloped. Apparently also because of the economic crisis is CRM in the Czech Republic begins to be used more. The main goal of implementing CRM is to help to company increase the quality of relationship and communication with customers. In this article are the most common definitions of CRM.

The main content of this article is about the analysing and comparing of Trading Income of selected companies doing business in the Czech Republic. There are compared selected companies with implemented information technology and business strategy CRM with companies without implemented CRM and how it could have an impact to the Trading Income of these selected companies. Has CRM implementation helped to increase the positive Trading Income during the economic crisis? Included is an analysis of Trading Income from 2007 to 2010 for selected companies grouped by number of employees. The conclusion summarizes the analysis of results and assumptions and benefits of CRM.
\end{abstract}

business strategy, competitiveness, CRM, customer relationship management, information technology, trading income

\section{INTRODUCTION}

At the present time when the majority of companies are still dealing with impacts of the economic crisis, new solutions how to restructure the company and keep customers are being searched. There are a lot of options how to solve it. This article deals in detail with utilization of technology and business strategy Customer Relationship Management (CRM) in a sample of selected companies and their Trading Income. The aims were comparing and analysing of Trading Incomes of selected companies with established technology and business strategy CRM with selected companies without implemented CRM and try to find some significant connections between implementing CRM in the selected companies and Trading Incomes during the economic crisis.

\section{WHAT IS CUSTOMER RELATIONSHIP MANAGEMENT (CRM) AND ITS DEFINITION?}

What is Customer Relationship Management and what to expect from CRM? According to research by Hynek and Janecek "Evaluation of the benefits of advanced technologies" conducted in the years 2008 to 2009 the company expected in particular to increase product quality, increase efficiency, retaining existing customers, improve communications with customers, identifying and predicting possible future demand and also to gain new customers and improve market competitiveness.

How is CRM defined? According to the available literature is not only one uniform definition of CRM. For example, Scott Fletcher defines CRM as a set of ideas and enterprise business processes, which have a direct 
impact on addressing, contact and customer retention, in the areas of marketing, sales and service. According to Schneiderman is CRM not only technology and information system, but also a business strategy focused on understanding our customers and based on anticipating the needs of current and future customers of the company.

Österle defines CRM as an alternative to increase turnover and profits of the company through the coordinated integration of all business contacts with its suppliers, business partners and customers. Storbacka defines CRM as follows: CRM is an interactive process aimed at achieving the optimum balance between corporate investments and meeting customer needs. Optimum balance is determined by the maximum gain of both parties. A little bit more concise definition is from Lawrence Handen: CRM is the process of addressing, maintaining and further developing relationships with profitable customers.

From the Czech definitions of CRM let us mention probably one known definition by Dohnal: CRM is comprised of employees, business processes and technology IS/ICT in order to maximize customer loyalty and consequently the profitability. It is part of corporate strategy and as such becomes part of corporate culture. Technologically CRM systems are using more potential and possibilities of the Internet.

It is clear that CRM have not yet one uniform and consistent definition. From the questionnaires mentioned Hynek and Janecek research in which CRM was included as one of the possibilities of advanced technology showed that management of companies are thinking under CRM mainly information systems. These systems provide on the market mainly companies Microsoft, SAP, Oracle, IBM and Dakota. Detailed analysis and comparison of their IS CRM solutions will be the subject of the further research.

CRM is not only the information system (IS). In high quality of information systems is CRM only one of their components. CRM is mainly a business and marketing strategies, including methodology, which aims to acquire customers in the company to keep, identify their needs, requirements, and consumer shopping behaviour and develop longterm relationship with him. From these customers the company have long-term benefits. This creates a lifelong customer value for the company (Customer Life-Time Value, Lehtinen). It includes not only what the customer brings us today, but what the customer can bring for the whole future collaboration (relationship).

\section{METHODS AND RESOURCES}

\subsection{The research methodology}

The sample of companies was made from data collected from questionnaires obtained during the Hynek and Janecek research. For this research in year 2011 was made a sample of selected companies which responded in the questionnaires that CRM have implemented or CRM have not implemented yet. Detailed information about the Trading Income was obtained from companies' websites and database Creditinfo. Subsequently were selected companies grouped by their size expressed by number of employees. Then was compared their Trading Incomes.

\subsection{The aims and assumptions of the research}

The main aim of the research was comparing Trading Income of the selected companies doing business in the Czech Republic in dependent on established technology and business strategy CRM with the selected companies without implemented technology CRM. The first assumption (Al) was that exist significant correlations among implementing CRM and increasing Trading Income. The second assumption (A2) was that companies with implemented CRM have higher Trading Income then companies without implemented CRM. The third assumption (A3) was that the selected companies with implemented CRM had better Trading Income during and after the crisis than those without implemented CRM.

\subsection{Composition of the sample of companies}

In the extensive questionnaire survey carried out by the Hynek and Janecek (2008) research were questions about the use of CRM. Obtaining of completely filled in questionnaires was extremely difficult. Addressed representatives of companies were usually referring to business secrets. However, after personal consultation with the management of the companies and guaranteeing the anonymity of the results they answered the questions and agreed with the subsequent processing. Total of 131 companies sent back completely filled questionnaires. Total of 29 from 131 companies

I: Dividing of companies by size

\begin{tabular}{lcc}
\hline \multicolumn{1}{c}{ The Number of Employees } & The Number of Companies & The Number of Companies with \\
CRM
\end{tabular}

Source: Own processing. 
answered questions about the use of CRM. From these companies 22 companies expressed that they have CRM implemented in the company and 7 companies expressed that they do not use CRM but will be implemented it soon. For purposes of further analysis the companies were divided according to their size expressed by number of employees. You can see it at the Table I.

\section{THE RESULTS OF THE RESEARCH}

For a better overview of analysed Trading Incomes of selected companies and for confirm or unconfirmed the assumptions were created graphs 1-4 (Figs. 1-4).

The surveyed companies which implemented CRM before or in the year 2009 but due to the economic crisis in years 2009-2010 their Trading Incomes increased less than was expected. The most of the surveyed companies declined Trading Income during the economic crisis years compared to non-crisis year 2007.

Readers who are interested in further details about the analyses of CRM systems and business strategy CRM are advised to look at researches by Nemecek, where are comparing Overall Turnovers and Trading Incomes of selected companies in the Czech Republic depending on implementing technology CRM.

In the Graph 1 (Fig. 1) are Trading Incomes of the selected companies with number of employees from 1 to 100. There are marked by circle the companies with ID number 6 and 9. These companies in the questionnaire indicated that they did not implement CRM before the economic crisis (in year 2008 or earlier). In the company number 6 had declined Trading Income in year 2009. It was caused by the main subject of their business telecommunications and repairing the mobile phones. In the company number 9 had economic crisis huge impact. Decline of their Trading Income was caused by the economic crisis and by the subject of business - secure of buildings.

The remaining companies with implemented CRM before the crisis had better financial results during the economic crisis than the companies which were implementing CRM during the crisis years 2009-2010. These small-size companies were very flexible during the economic crisis and most of them had positive financial results.

In the Graph 2 (Fig. 2) are Trading Incomes of the selected companies with number of employees from 101 to 200 . There are marked by circle companies with ID number 15 and 16. These companies in the questionnaire indicated that they did not implement CRM before the economic crisis (in year 2008 or earlier). In these companies were significant impacts of the economic crisis during the years 2009-2010. These companies compared to the companies with implemented technology CRM before the crisis was not able to increase their Trading Incomes in the year 2010. It could be caused by worse communication with their suppliers and customers during the economic crisis.

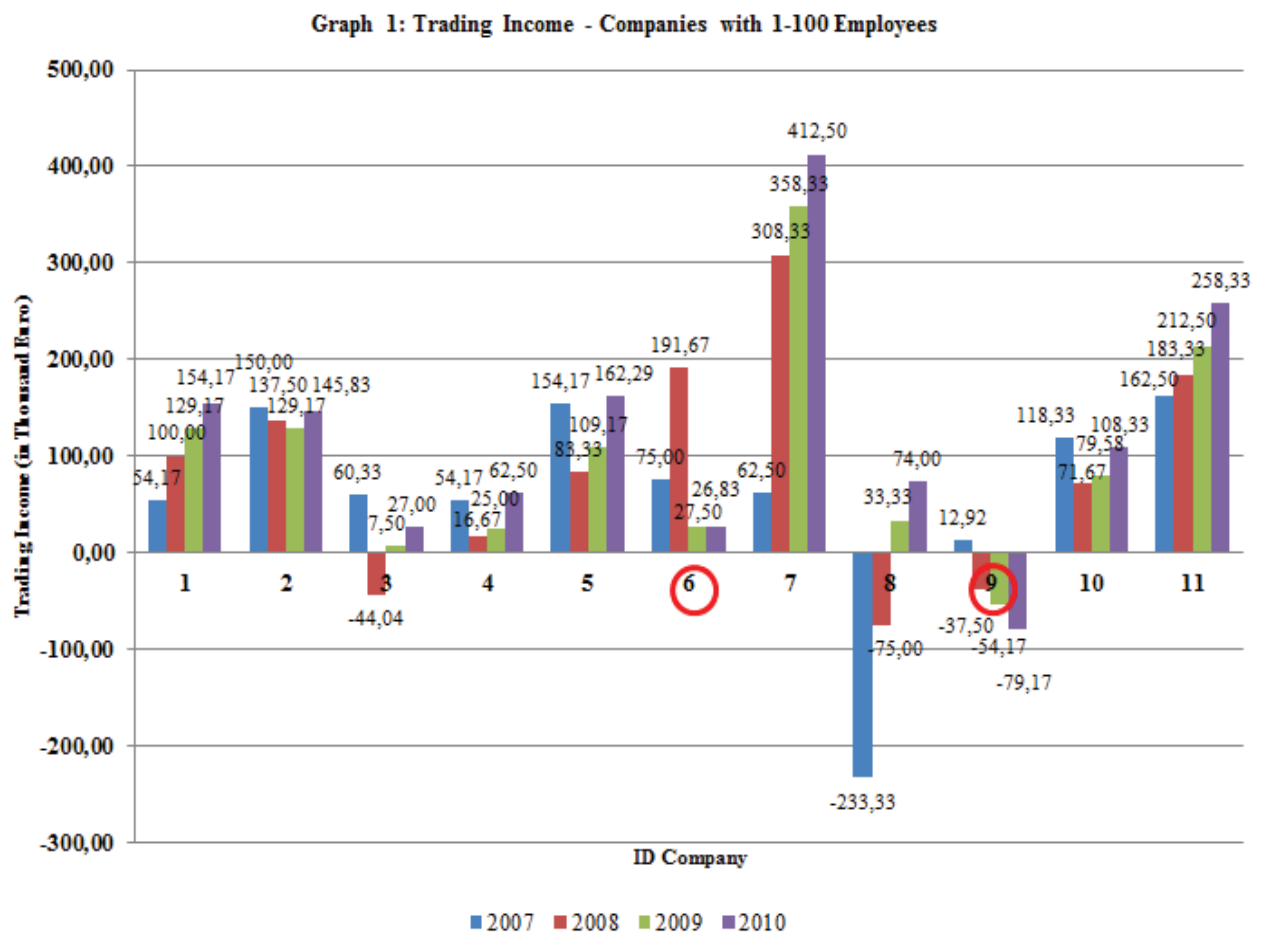

1: Trading income of selected companies with 1-100 employees

Source: Own processing.

In the circle is company which implemented CRM during the economic crisis. 


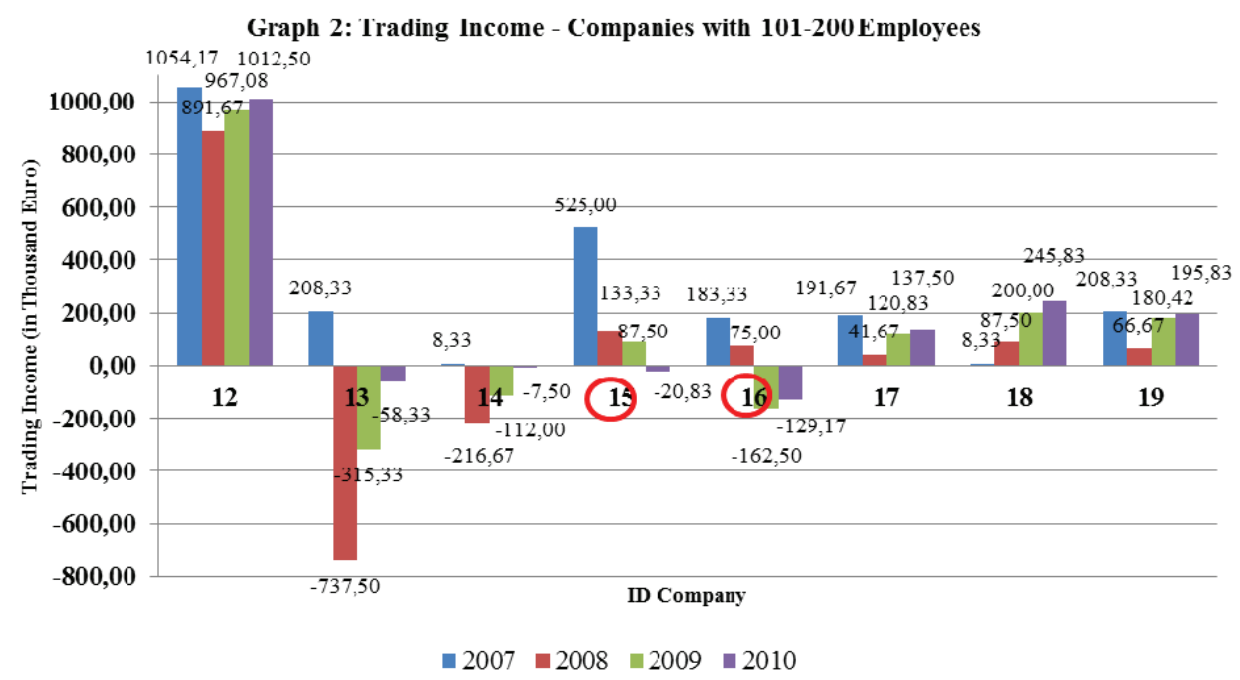

2: Trading income of selected companies with 101-200 employees Source: Own processing.

In the circle is company which implemented CRM during the economic crisis.

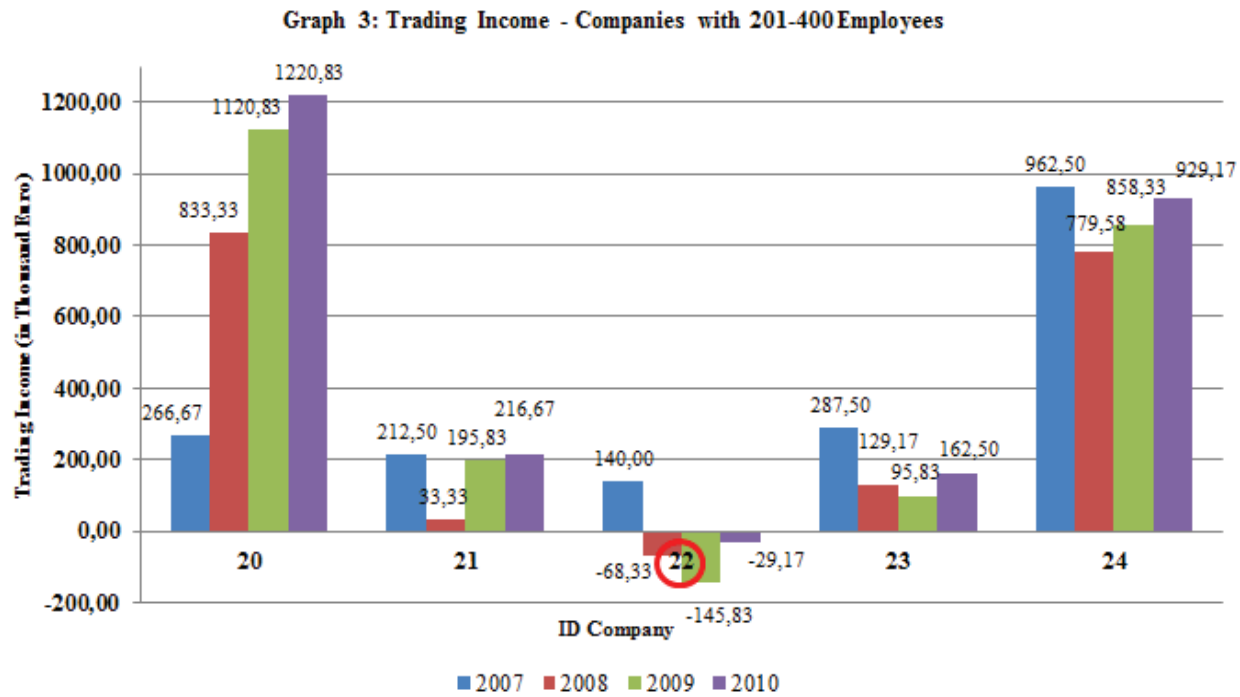

3: Trading income of selected companies with 201-400 employees Source: Own processing.

In the circle is company which implemented CRM during the economic crisis.

The companies with implemented CRM before the economic crisis were able to have standard and good communication with their suppliers and customers and were able to quickly make new contracts in the year 2010.

In the Graph 3 (Fig. 3) are Trading Incomes of the selected companies with number of employees from 201 to 400 . There is marked by circle company number 22 without implemented CRM before the economic crisis (in year 2008 or earlier). Because of the economic crisis this company had significant losses in Trading Income and was near the bankruptcy. For this company it could be recommended implementation CRM before economic crisis. Main subject of business of these company is sales and services of agricultural and forestry machines. If the company has implemented CRM before the crisis, it could better communicate with their customers and develop permanent relations with them. It could also identify customer needs and their current views on the products of the company. It could help this company to improve competitiveness earlier than nowadays after implement CRM. The remaining companies with implemented CRM better overcome the crisis and had only positive Trading Incomes.

In the Graph 4 (Fig. 4) are Trading Incomes of the selected companies with number of employees higher than 401. There are marked by circle companies number 26 and 28 without implemented CRM before the economic crisis (in year 2008 or earlier). Main subject of business of 


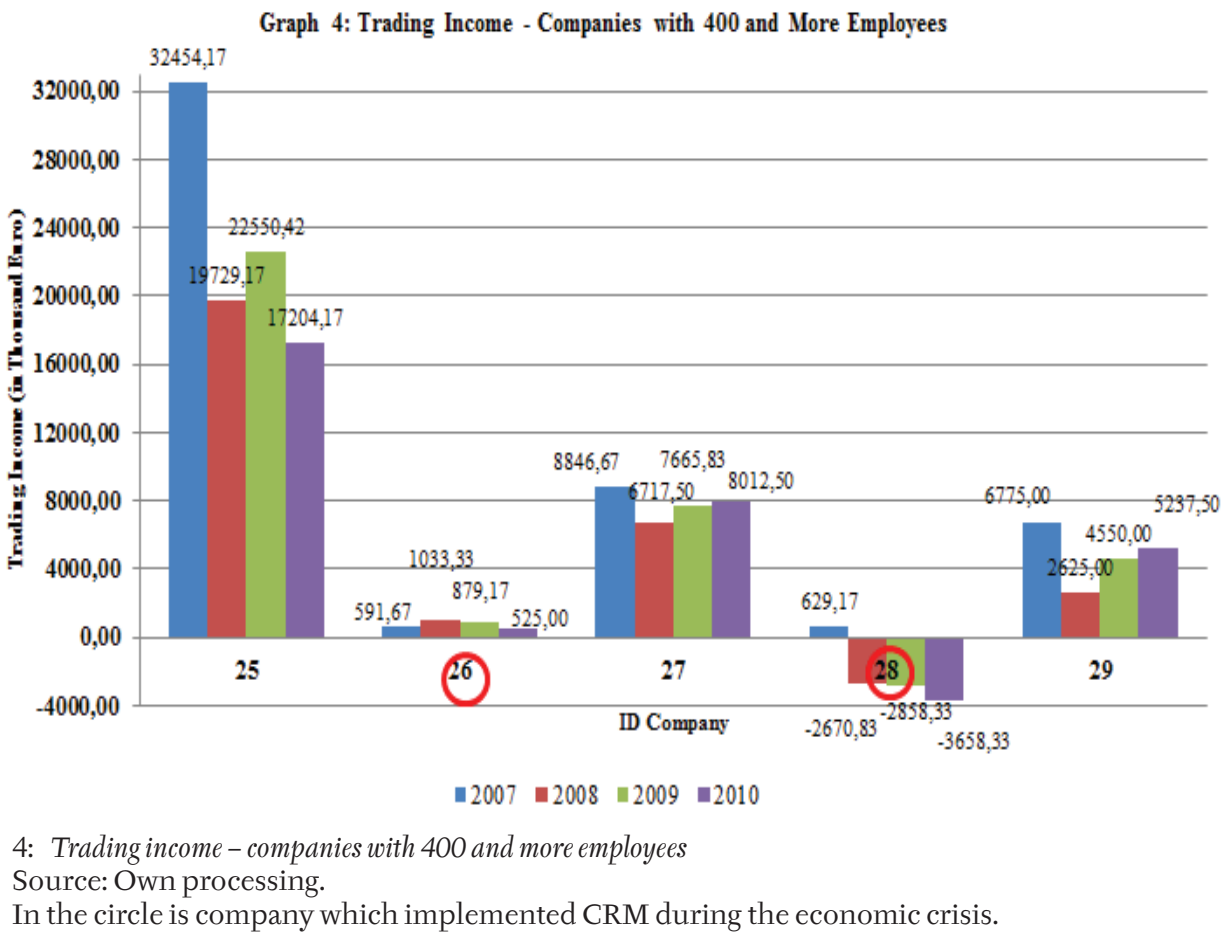

company number 26 is producing high quality and in the world unique demand specific types of components for machineries such as for example turbines, marine propellers and plates. Main subject of business of company number 28 is software solutions for business companies. In these big companies is significant decreasing trend of Trading Income during the crisis years 20092010. These companies compared to the companies with implemented CRM before economic crisis had worse financial results during the economic crisis. In the companies with CRM is significant quick increasing and positive trend of financial results during the year 2010. They had positive Trading Income for all the time of the research period. CRM had positive impact for keeping customers and their trust for the companies during the crisis.

\section{CONCLUSION AND SUMMARY}

According to the analysis the first assumption (Al) was not proved and confirmed. Significant correlations among implementation of information technology and business strategy Customer Relationship Management (CRM) and increasing Trading Incomes were not found.

The second assumption (A2) was not proved and confirmed too. The companies had not higher Trading Incomes after the implementation of CRM in compared to the companies without CRM. More important was their subject of business and size of the company.

The third assumption (A3) was proved and confirmed. The selected companies with implemented CRM had significant better Trading Income during and after the economic crisis than the companies without implemented CRM. The companies with implemented CRM had positive trend of financial results in the year 2010 after the economic crisis. The companies without CRM had mainly negative trend of financial results in the year 2010.

According to the previous researches by Nemecek was found that small and medium-sized companies with the number of employees 1-100 and 101-200 use mainly CRM software solutions by Microsoft Dynamics CRM and Oracle CRM. In large and larger companies with number of employees 200-400 and 401 and more was showed tendency to rather use CRM within complex IT services through Cloud Computing technology. Mainly SAP CRM with other SAP products and IBM CRM products were used. Detailed analysis and comparison of CRM software solutions will be the subject of the further research.

In this research was also found that the information technology and business strategy CRM could be a significant advantage for all size of companies during the economic crisis. 


\section{REFERENCES}

BERNDT, A., BRINK, A., 2008: Relationship Marketing and Customer Relationship Management, Juta and Co Ltd., Pinetown Printers, South Africa.

BROWN, S. A., 2000: CRM A Strategic Imperativ in the World of E-business, John Willey and Sons Inc., USA.

Creditinfo - Firemní monitor, 2010: Database on DVD by Creditinfo Czech Republic, s. r. o., Praha.

DOHNAL, J., 2002: Customer Relationship management, Řízení vztahů se zákazníky, Praha: Grada.

HYNEK, J., JANEČEK, V., 2009: Evaluation of the Benefits of Advanced Technologies, Hodnocení přínosů vyspělých technologií, Hradec Králové: Gaudeamus.

KUMAR, V., REINARTZ, W. J., 2006: Customer Relationship Management-A Databased Approach, John Willey and Sons Inc., USA.

LEHTINEN, J. R., 2007: Aktivní CRM - Řízení vztahů se zákazníky, Grada Publishing.

NĚMEČEK, J., 2010: CRM and Competitiveness of Selected Companies, CRM a konkurenceschopnost vybraných firem, In: Národná a regionálna ekonomika VIII. Košice: Technická univerzita v Košiciach, pp. 693-700, ISBN 978-80-553-05172.
NĚMEČEK, J., 201l: CRM and Income Trading of Selected Companies, CRM a výsledky hospodaření vybraných firem, In: Journal of Competitiveness. Zlín: Univerzita Tomáše Bati ve Zlíně, Fakulta managementu a ekonomiky, pp. 75-81, ISSN 1804171X (Print), ISSN 1804-1728 (On-line).

NĚMEČEK, J., VAŇKOVÁ, L., 2011: CRM and Cloud Computing, In: Recent Researches Applied Informatics. Prague, WSEAS Press, pp. 255-259, ISBN: 978-1-61804-034-3.

ÖSTERLE, H., MUTHER, A., 1998: Electronic Customer Care - Neue Wege zum Kunden, Wirtschaftinformatik 40.

SCHNEIDERMAN, N., YIH, A., 2001: The Emerging Face of Customer Relationship Management, Wedbush Morgan Securities.

SOUKAL, I., HEDVIČÁKOVÁ, M., 2010: Retail Core Banking Services E-banking Client Cluster Identification, In: Procedia Computer Science Journal. Vol. 3. Elsevier, pp. 1205-1210. ISSN: 1877-0509.

STORBACKA, K., 2002: Řízení vztahů se zákazníky, Praha: Grada Publishing.

SVOBODOVÁ, L., 2011: Advanced Manufacturing Technology Utilization and Realized Benefits, In: International CSCC Multiconference, Corfu, July 14-17, WSEAS Press.

Address

Ing. Jan Němeček, Katedra ekonomie, Univerzita Hradec Králové, Hradecká 1249/6, 50003 Hradec Králové 3 , Česká republika, e-mail: jan.nemecek@uhk.cz 